\title{
Criteria of livable public spaces quality. Case study analysis on the example of selected public spaces Lublin, Poland
}

\author{
Agnieszka Chęć-Małyszek \\ https://orcid.org/0000-0001-6004-0635 \\ a.chec-malyszek@pollub.pl \\ Department of Architecture and Urban Planning, Lublin University of Technology
}

\begin{abstract}
The aim of the research presented in this paper was to assess the attractiveness of selected public spaces located in the downtown of Lublin in a specific moment of time - after the experience of the Covid-19 pandemic. The research made it possible to determine the predisposition of studied spaces to be places providing peace, relaxation, tranquility in which people willingly spend their free time. At the same time, the results of the questionnaires were confronted with the surveys of spaces according to Jan Gehl's methodology of 12 Quality Criteria of Successful, Livable Space. The aim of the study was to check whether the popularization of the idea of creating a city for the people has a real impact on the realization of the newest public spaces which can be considered as new landmarks for Lublin. Selected public spaces of different kinds were analyzes according to fulfilling 12 Quality Criteria and with user's perception survey (questionnaire).
\end{abstract}

Keywords: Livable Public Space, Public Green Spaces, User's perception, Identity

\section{Introduction}

Public spaces are an integral part of cities, but nowadays we expect more from them than before. This is especially true in terms of the quality of public spaces and the contribution of nature to their creation. The emergence of the Covid-19 pandemic has made it clear how necessary it is to spend time in public spaces and how important it is for people's well-being and mental health to go outside their homes. The multitude of activities traditionally and intrinsically linked with public spaces, such as travel, commerce, collective cultural events, sports, were restricted due to the Covid-19 pandemic. The reopening of public spaces for public in Poland took place in the spring of 2021. The moment when public spaces became accessible became a pretext for conducting a qualitative study of selected public spaces in Lublin, concerning the perception of these spaces by the inhabitants after the pandemic or during its pause. The time of the research was also a pretext for determining the role of public spaces in the situation of the covid-19 pandemic.

The research also included the influence of Jan Gehl's theory concerning principles of successful, livable public spaces design on the latest realizations of public spaces in Lublin. Professor Jan Gehl has visited Lublin twice. The first time was in 2008, as part of the International Architecture Workshop organized by the Mayor of Lublin. It was a period of intensive preparations for announcing a competition for revitalization works of the main public space of the city center - Litewski Square. The workshop gave rise to a public discussion about the sensitive urban space, its quality and the directions for necessary changes. The next time Jan Gehl visited Lublin was in 2014, when, on the initiative of local NGOs, the city hall, public institutions and the academic community, the Year of Jan Gehl in Lublin was declared. Accordingly, a number of events were held in 2014 to popularize good design of public spaces and to point to a participatory model of urban management [1]. Thus, professor Jan Gehl's methodology is known in the local environment not only to architects and urban planners, but also to urban activists and people involved in shaping public spaces. 


\section{Materials and Methods}

The aim of this study is to identify the factors determining the attractiveness of modern livable urban spaces on the example of Lublin, so that they are conducive to rest, relaxation and emotional development at this particular moment: after their reopening during the pandemic. It is difficult to assess whether this moment can already be called post-pandemic or whether it is just a pause in the global pandemic. Another aim is to check whether the influence of the ideology of designing public spaces according to Professor Jan Gehl, their outstanding researcher, is visible. The research of selected public spaces within Lublin was based on research methods used in the evaluation of such spaces in cities. These include research walks, expert evaluation in terms of field observations and photographic documentation, as well as collecting user opinions through surveys collecting data about user's perception [2]. Information available on websites and literature was also used for further description of case studies. Studied Areas were analyzed according to fulfilling 12 Quality Criteria of Successful, Livable Space created by Jan Gehl as a tool which works in a variety of public space types: plazas, parks, squares, and streets. Criteria concern: protection, comfort and enjoyment. The surveys (observing and assessing individual public space whether they live up to the criteria) were performed by the authors from 15.05.2021 till 15.08.2021 in each selected space in weekends and during the week. For every criterion, scores were given regarding selected aspects assigned to a given criterion: 1, 0.5, or 0 (meaning fulfilling the criterium, in between, or no, respectively). In case of Comfort criterion elements analyzed were more detailed so scores given in range 0.5-0 maenad meaning fulfilling the criterium or no [Table 2].

The methodology of The Twelve Quality Criteria was also checked for two case studied public spaces created on green roofs, which are relatively modern solutions. The aim of the research was also to check the usefulness of this method in the context of the convergence of its results with the users' assessment.

Surveys were carried out to determine which elements of their development are factors determining their attractiveness. The research was conducted between May and June 2021 on a group of 200 respondents of different ages currently living in and around Lublin. Out of those who answered the questionnaire, 142 were women and 58 were men. Half of the respondents were currently studying, the rest were between 35 and 48 years old, with the majority of women. The choice of the research group was dictated by the preliminary understanding of the user group profile.

As a result of the presented research, attention was drawn to the elements which directly influence the attractiveness of given spaces, thus increasing the frequency of their visits. The assessment of the attractiveness of selected areas took into account: aesthetic, functional, social and emotional values. The most important research issue was to show the relationship between urban spaces and their attractiveness in social terms, with particular attention paid to the role of art as a tool for reviving them.

In the research, the free Microsoft Office 365 platform (www.office.com) was used, in which a questionnaire containing 22 questions with multiple choice options was prepared. The application allowed for efficient distribution of questionnaires, their timely collection and calculation of results. Spatial information databases (GIS) were used: https://mapy.geoportal.gov.pl/imap/Imgp_2.html?gpmap=gp0, and publicly available websites to obtain information about the current situation of the city.

For the purpose of this article a review of the literature on the subject was carried out with particular emphasis on the latest publications concerning the valuation of public spaces and their role in the post-covid city. Five public spaces in Lublin were selected as case studies and subjected to detailed analyses: which included on-site observations, analyzing historical and social background, activities and functions currently occurring in the selected spaces, current technical and aesthetic condition, and the presence of elements of art and nature. The field surveys concerned relations between scale of public spaces, its programming (commercial and cultural initiatives), furnishing and landscaping were held in the same time as assessing The Twelve Quality Criteria). To interpret the results, the methodology developed by professor Jan Gehl [3-5] was adopted, which can now be considered "classical" in terms of the assessment of quality criteria for public spaces. It was against this background that the research questions were formulated and then used in the survey, referring to selected public spaces in Lublin.

The survey considered factors influencing the user's perception of the immediate environment, which are directly related to residents' sense of well-being and the satisfaction of their needs in terms of function and 
aesthetic experience. Although the studied areas differs in scale and typology (squares, parks and green roofs), all of them are considered to be landmarks places in Lublin, with strong identity.

Conclusions were drawn on the basis of survey showing quantitative data and perceptions of users, as correlated with the level of livable and successful public space.

\section{Case study areas selection}

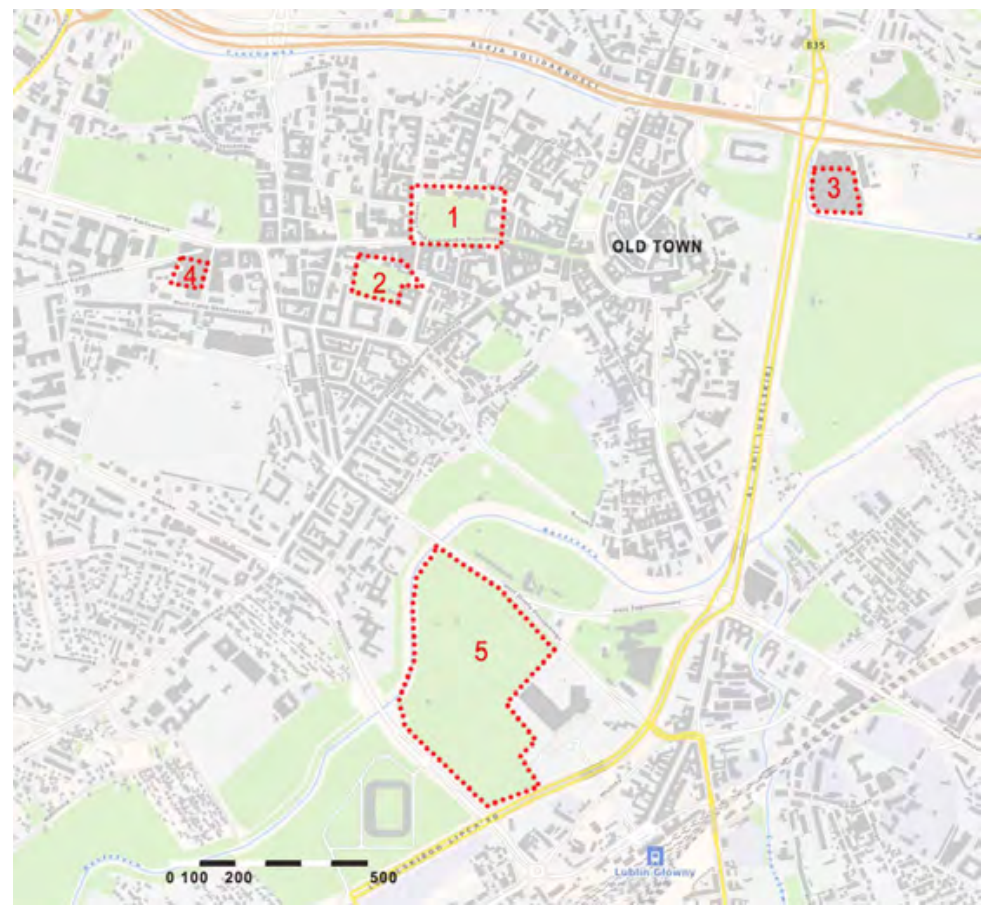

Fig. 1. Distribution of the studied spaces in the center of Lublin

1 - Litewski Square, 2 - square at the Cultural Centre, 3 - Galeria Vivo roof, 4 - roof of the Centre for the Meeting of Cultures, 5 - People's Park (Park Ludowy).

Lublin is one of the major Polish cities. The city is located in central-east Poland about $160 \mathrm{~km}$ from capital Warsaw. $9^{\text {th }}$ location in terms of population (about 340000 in 2019) and $16^{\text {th }}$ location in terms of area $\left(147.5 \mathrm{~km}^{2}\right)$. The population density is 2304 people per km2 (in 2017). Lublin can be classified as a medium-sized, university city (about 80,000 students) with aspirations towards metropolitan development. The research background is provided by the results of a study on aspects related to public spaces and urban landscape design as well as the needs of the inhabitants, carried out by the Lublin Research Group for the purposes of developing the Lublin 2030 Strategy [6-7].

Five public spaces differing in time of creation, leading function, size and character were selected for analysis [Fig. 1]. These spaces enjoy general popularity among users. The common feature linking them is the time of refurbishment, revitalization, or the introduction of significant changes which have increased the popularity of these places - the last 5 years. As the spaces differ in scale character and spatial context, it was considered that each could be representative of its type [Table 1]:

- Case Study 1 - Litewski Square - the main multifunctional city square,

- Case Study 2 - square at the Cultural Centre (CK) - an intimate square in the city center,

- Case Study 3 - Galeria Vivo roof - a space accompanying a commercial function (the roof of a shopping mall),

- Case Study 4 - roof of the Centre for the Meeting of Cultures in Lublin (CSK) - space accompanying the cultural institution,

- Case Study 5 - People's Park (Park Ludowy) - a contemporary active recreation park of city-wide significance. 
Table 1. Surveyed public spaces - summary of key data concerning relations between scale, programming, landscape and furnishing

\begin{tabular}{|c|c|c|c|c|c|}
\hline & $\begin{array}{l}\text { Case Study } \\
\text { Area } 1\end{array}$ & $\begin{array}{c}\text { Case Study } \\
\text { Area } 2 \\
\text { Square at the } \\
\text { Cultural Centre }\end{array}$ & $\begin{array}{l}\text { Case Study } \\
\text { Area } 3 \\
\text { Galeria } \\
\text { Vivo roof }\end{array}$ & $\begin{array}{c}\text { Case Study } \\
\text { Area } 4 \\
\text { Roof of the } \\
\text { Meeting of } \\
\text { Cultures Centre }\end{array}$ & $\begin{array}{c}\text { Case Study Area } 5 \\
\text { People's Park } \\
\text { (Park Ludowy) }\end{array}$ \\
\hline $\begin{array}{l}\text { Surface area } \\
\text { estimate [ha] }\end{array}$ & 2.65 & 1.25 & 1.0 & 0.31 & 24 \\
\hline $\begin{array}{l}\text { Form of } \\
\text { ownership }\end{array}$ & Public & Public & Private & Public & Public \\
\hline $\begin{array}{l}\text { Year of } \\
\text { construction } \\
\text { / year of } \\
\text { modernization }\end{array}$ & $1823 / 2017$ & $\begin{array}{l}2015 \text { Continuous } \\
\text { change and } \\
\text { addition of } \\
\text { spaces by } \\
\text { different actors }\end{array}$ & 2017 & 2016 & 2019 \\
\hline $\begin{array}{l}\text { Permanent } \\
\text { attractions }\end{array}$ & $\begin{array}{l}\text { Playgrounds } \\
\text { Monuments } \\
\text { commemorating } \\
\text { historical events: } \\
4 \text { pieces }\end{array}$ & $\begin{array}{l}\text { Playgrounds, } \\
\text { Gym, } \\
\text { Monument to the } \\
\text { Sybirak Mother, } \\
\text { Mural on the wall } \\
\text { separating the } \\
\text { square }\end{array}$ & $\begin{array}{l}\text { Seats with } \\
\text { panoramic views } \\
\text { of the city, } \\
\text { Outdoor gym }\end{array}$ & Viewing terrace & $\begin{array}{l}2 \text { large playgrounds, } \\
\text { Dog runs, } \\
\text { Outdoor gym } \\
\text { Workout and fitness } \\
\text { area, } \\
\text { Acoustic pathway, } \\
\text { Didactic } \\
\text { philosophical path, } \\
\text { Volleyball posts and } \\
\text { nets, } \\
3 \text { boules pitches } \\
\text { Chess tables }\end{array}$ \\
\hline $\begin{array}{l}\text { Temporary } \\
\text { attractions }\end{array}$ & $\begin{array}{l}\text { Fountain } \\
\text { Mulitmedia shows, } \\
\text { Concerts, } \\
\text { State ceremonies, } \\
\text { Christmas } \\
\text { decoration, } \\
\text { Artistic } \\
\text { installations }\end{array}$ & $\begin{array}{l}\text { Art installations, } \\
\text { Photography } \\
\text { exhibitions }\end{array}$ & $\begin{array}{l}\text { Summer cinema, } \\
\text { Café, } \\
\text { Playground, } \\
\text { summer "beach", } \\
\text { deckchairs }\end{array}$ & $\begin{array}{l}\text { Café, } \\
\text { Apiary }\end{array}$ & $\begin{array}{l}\text { Didactic water plant } \\
\text { garden, } \\
\text { Amphitheatre with } \\
\text { fountain }\end{array}$ \\
\hline $\begin{array}{l}\text { Natural } \\
\text { elements }\end{array}$ & $\begin{array}{l}\text { High and medium } \\
\text { greenery, } \\
\text { Annual } \\
\text { ornamental plants, }\end{array}$ & $\begin{array}{l}\text { Tall greenery, old } \\
\text { trees, lawn, } \\
\text { No decorative, } \\
\text { No ornamental } \\
\text { plants }\end{array}$ & $\begin{array}{l}\text { Green roof: } \\
\text { planting of } \\
\text { perennials, vines } \\
\text { and trees, } \\
\text { Partially flat roof }\end{array}$ & $\begin{array}{l}\text { Green roof: } \\
\text { planting of } \\
\text { perennials, } \\
\text { climbers and } \\
\text { trees, } \\
\text { Partially flat roof }\end{array}$ & $\begin{array}{l}\text { High and medium } \\
\text { greenery, natural } \\
\text { riparian greenery, } \\
\text { Boxes for birds: } \\
\text { kingfishers and } \\
\text { hoopoes }\end{array}$ \\
\hline $\begin{array}{l}\text { Number of } \\
\text { public seating } \\
\text { places }\end{array}$ & $\begin{array}{l}650 \text { seats in total, } \\
\text { Different kinds of } \\
\text { benches }\end{array}$ & $\begin{array}{l}200 \text { seats in total, } \\
3-4 \text { person } \\
\text { benches }\end{array}$ & $\begin{array}{l}\text { c.a. } 80 \text { benches } \\
\text { additional: } \\
\text { possibility of } \\
\text { seating on the } \\
\text { stairs }\end{array}$ & No free seats & $\begin{array}{l}702 \text { seats in total, } \\
150 \text { park 4-person } \\
\text { benches, } \\
24 \text { tables (including } \\
12 \text { with chessboard), } \\
72 \text { chairs, } \\
15 \text { picnic tables, } \\
30 \text { deckchairs }\end{array}$ \\
\hline $\begin{array}{l}\text { Biologically } \\
\text { active area } \\
\text { estimated } \\
\text { percentage }\end{array}$ & $\begin{array}{l}26 \% \text { without } \\
\text { fountain }\end{array}$ & c.a. $80 \%$ & $\begin{array}{l}\text { Green roof }- \text { c.a. } \\
70 \% \text { of total roof } \\
\text { area }\end{array}$ & $\begin{array}{l}\text { Green roof - c.a. } \\
70 \% \text { of total roof } \\
\text { area }\end{array}$ & Over $90 \%$ \\
\hline
\end{tabular}




\section{Background - the role of urban public spaces in the context of Covid-19}

Nowadays, the shaping of cities is primarily about the proper provision of friendly public spaces of varied character, forming a continuous system on a city scale. Lorens defined public space as "a fragment of urban space, which - through its location and design - is intended to build direct social contact, while remaining accessible to all [8]". Urban public spaces are characterized by openness, accessibility and transparency [9-14], while aesthetics, testify to the quality of the city and social life $[12,14]$. Public space is a part of the city which is used by residents and other users, who perceive its elements and subject it to constant evaluation. A public space is a shared space, which usually has a public owner (state or local government) and is characterized by semiotics that build up spatial identifications, which enable social interaction and communication [15]. However, public spaces are not necessarily public in terms of ownership and management. On the contrary, they can become more "public" when multiple actors - including private ones - are involved in the planning and management of urban areas. Furthermore, private actors can provide the resources needed for the project [15]. From a user perspective, an urban public space can be described as a dedicated area in a city that attracts users, is accessible to them, is aesthetically pleasing, offers opportunities for confrontation, and where people want to meet, feel safe and make social connections.

The emergence of the Covid-19 pandemic was immediately noticed by researchers of public spaces and has raised new issues regarding the utilitarian, functional and sanitary aspects that have a direct impact on design $[16-19,30]$. In many cases, there is a need to redesign selected public spaces to ensure safety [12] and also to think holistically about urban management to increase public health $[12,14]$. Restrictions on the use of public spaces caused by the Covid-19 pandemic resulted in reduced use of spaces also after the restrictions were removed. Research conducted in the UK has additionally shown a relationship between the socio-economic situation of users and the frequency of use of public spaces. The restrictions exacerbated existing inequalities [15].

Post-pandemic cities are reclaiming public spaces anew. In many ways, measures of containment and physical distancing have contributed to a greater understanding of the importance of public space as a place for gathering and meeting basic social needs. City dwellers are now more aware of the important role of this space as a living environment essential for their physical and mental well-being. The discussion about the contemporary shape of public spaces [16] is also a discussion about the validity of existing paradigms in the field of their design [17]. With a renewed focus on the ability of urban public spaces to stimulate social connectedness and social well-being, our cities can be rebuilt and reconfigured post-pandemic. The enjoyment of public spaces and the attractions they offer can play a key role in this transformation of urban life [18].

The easy and general availability of open green spaces plays a key role in ensuring mental health, which is particularly important in times of pandemic [19].

Creating intimate green spaces [20] and improving the adaptability of streets, squares and semi-public spaces can help to provide a level playing field for all urban dwellers, in terms of improving mental health during pandemics. Multifunctionality seems to be the most appropriate approach in the design of public spaces. In the absence of being able to host specific and especially commercial functions (e.g. mass events, fairs, etc.) these spaces are still able to improve the mental health and comfort of users by continuing other functions, including providing opportunities for physical activity and offering regenerative benefits during lockdown. Greater use of amenities - such as natural elements, pedestrian and cycling infrastructure and urban furniture - and safety in streets and squares can improve the adaptation of these spaces to pandemonium [21].

Negative feelings accompanying confinement to one's own living spaces increase the demand for outdoor spaces. Restrictions and the introduction of social distancing have had the greatest impact on the use of public spaces in recent months. At the same time the use of individual means of transport, including cycling, has increased, and many people have started to walk more, seeing this not only as an opportunity to communicate but also to keep physically and mentally fit.

\section{Background - the role of nature in the quality of contemporary public space}

Public space in a modern city has primarily social functions. Scientific research has shown a direct relationship between the aesthetic quality of public space development and the presence of natural elements in it and the 
psychological well-being of people, as well as specific behaviours and feelings such as: increased feelings of anger and aggression among drivers driving cars in areas devoid of greenery [22]. The presence of public green space, directly linked to residential zones, is a key element in influencing the quality of life, as well as bridging socio-economic gaps, which is particularly important for children [22]. Jennings and Bamkole [24] point to the relationship between the cultural ecosystem services of urban green spaces, social cohesion (as a social determinant of health) with social and health outcomes. In the case of public green space, there are many studies confirming the direct relationship with its occurrence and the public health status of urban dwellers, but there is still a need to continue these studies [25] and to expand them to include an urban view, allowing us to consider how cities should be shaped in post Covid-19 era [26].

Research shows that being surrounded by greenery or nature is beneficial to human health and psychological well-being [27]. Contact with nature helps to feel and function well [28], increases the sense of life satisfaction, eliminates anxiety, improves vitality, influences creativity, and contributes to increased pro-social behaviour [29] and improved mental health of people [30]. Being in publicly accessible green areas allows for rest, relaxation, relaxation and stress relief, and contact with greenery is a source of pleasure.

Nowadays the use of natural elements in the creation of public spaces is not only a trend, but also an expression of social responsibility. Highly developed industry and technology have led to humans interfering more and more drastically with the natural environment, causing irreversible negative consequences of their actions. Increasing social awareness of nature conservation contributes to the establishment of the concept of sustainable design and the promotion of a healthy lifestyle. One that is no longer just a trend, but a necessity. Urban greenery in urban planning is now treated as a system - green infrastructure, the continuity of which is essential for the proper functioning of the city. Different forms of greenery are desirable, both naturally occurring on undeveloped land, planned and newly introduced [31]. In recent years, there has been an increased interest in urban agriculture and a perceived need to introduce species biodiversity into cities [32]. Flower meadows replacing lawns, urban community gardens, apiaries or allotments are gaining popularity. Many cities (including Lublin) limit the frequency of mowing lawns and street greenery, which is aimed at improving water relations in the city.

\section{Background - the role of art in the quality of public space}

The elements of art in urban space have always accompanied man, but their role in the creation of public spaces has varied. Artistic products have decorated and adorned a given place, commemorated history, and evoked various (positive and negative) aesthetic experiences [33]. Nowadays, the multiplicity of art forms allows it to be more widely used in urban spaces and to enhance its social impact [34]. The elements of art in cities can have a purely visual function, often becoming an element of city promotion that attracts tourists [35]. At the same time, art in public space is often used during revitalization processes [36], especially that which provokes the audience to actively participate in it [37]. Different types of artistic works should be counted as additional elements of public spaces, enriching their attractiveness. Art, in permanent or temporary form, gives individual character to particular places by introducing new forms, colours, sounds or materials $[40,41]$ and enriches the symbolic layer of the city.

Art in public space is not always and has not always been accepted by the public, but it is a barometer of social moods, which can often be interpreted quite differently than the creator intended. Characteristic elements of art give a visual identity to a place, aestheticize it, make it more attractive and above all satisfy the social need to experience beauty [40]. Additionally, they are often good landmarks that distinguish a given space. The inclusion of art in public space makes any environment take on a pedagogical dimension [41].

Art in public space makes public the artwork-receiver relationship, during which contact is made with artistic forms of interference in the spatial fabric of the city [42]. The contact with art leaves traces in the public consciousness, regardless of whether the artwork interested, shocked or bored. Consequently, interactions of a social, cultural and economic nature occur. Aesthetic experiences accompanying the recipient not only consist in reception, but in entering into a relationship with the work of art along with the whole instrumentarium of familiar notions, signs, beliefs, experiences and emotions. We can, therefore, consider art in public space as an important component of culture that goes beyond the classical framework of thinking about artistic creation 
and works of art. It is art that demands, conditions and aspires to act. Engaging the viewer generates the potential to create social capital that serves a community of interests, building the cohesiveness of a group of people, thus providing them with identity and security. The possibility to participate in the reception of art in common places not only contributes to the aesthetic value of these spaces, but also triggers in the users the need to share them. Such places quickly become important and frequently visited points on city maps.

Lublin has a long tradition of introducing elements of art into public spaces. In 1976, the first Lublin Visual Arts Meetings were held. The artists who took part in the Meetings enriched the space of housing estates of Lublin Housing Cooperative with works of contemporary art such as open-air sculptures, installations or mosaics and wall paintings on publicly accessible parts of buildings. In the case of Lublin, the city's cultural policy has been significantly visible in recent years. Many of the actions taken during the candidature for the title of European Capital of Culture are continued to this day, which involves the permanent presence of various forms of art in public spaces. Unfortunately, the year 2020 was exceptional - most cultural mass events were cancelled.

\section{Results}

\section{Study Area 1: Litewski Square - Multifunctional main square}

Since its creation in the 1820s, Lithuanian Square has been one of the most important places on the map of Lublin. Its functions have evolved over time: from a drill square, through a representative square surrounded by official buildings, to being developed as a recreational space after World War II. However, regardless of the time of its existence, it has always been, and still is, a representative space, acting as the city's salon during national celebrations and important cultural events. At the same time, it is an important space of public greenery of great historical significance [43].

a)

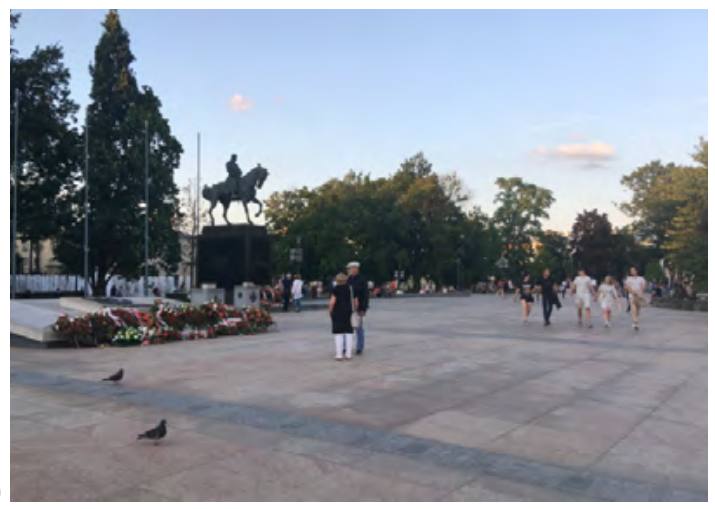

C)

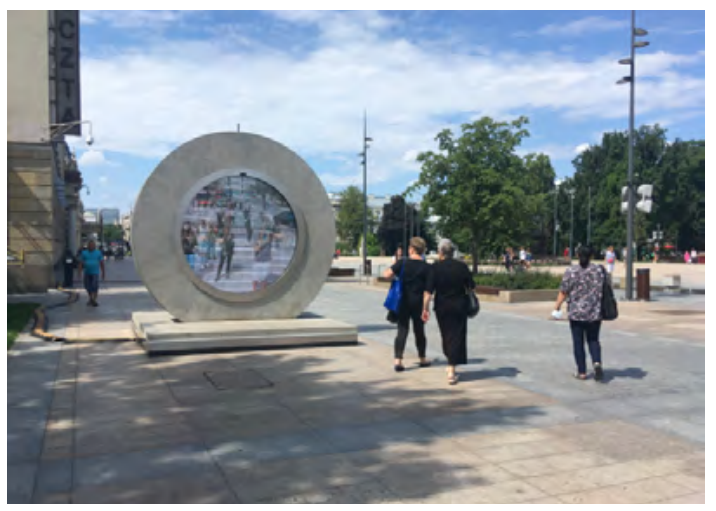

b)

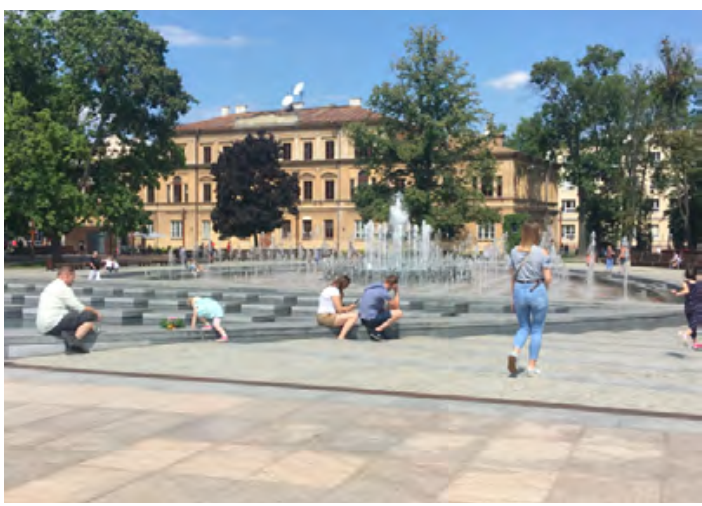

d)

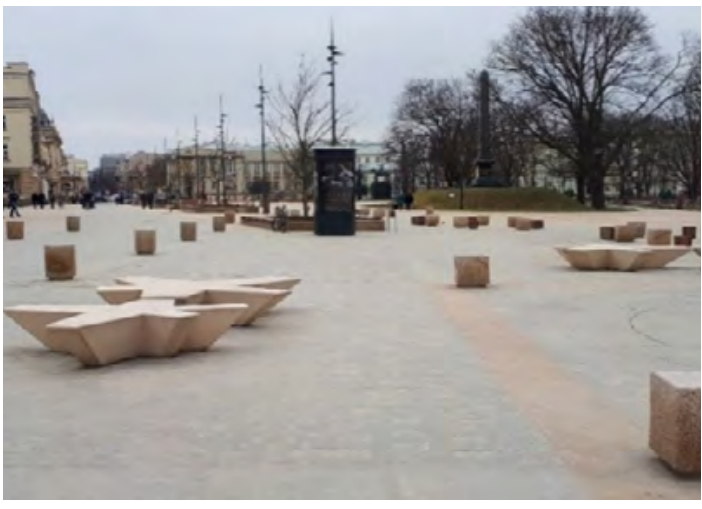

Fig. 2. Characteristic elements of Litewski Square. (a) - historical monuments, (b) - fountain, (c) - temporary art installations (Portal to Vilnius - live camera), (d) - pedestrian communication area 
The revitalisation works leading to the current shape of the space were completed in 2017 [Fig. 2]. The new development of the square assumed excluding it from vehicular traffic, thus extending the pedestrian route stretching from the castle, through the Old Town and Krakowskie Przedmieście Street, which was excluded from traffic. The existing functions and elements were retained, changing and modernising their architectural forms. The square is divided into two parts: an extension of the pedestrian communication axis towards the old town, which acquires a representative character during celebrations, and the northern part - the recreational part with separate areas for playgrounds, seats and benches, meeting places and greenery. Both parts are connected by the square's greatest attraction - a multimedia fountain. Along the extended part of the promenade there is a series of floor fountains, which diversify the "communication" part of the square. After revitalization, the square has become a meeting place for whole families with children, who often come to Lublin from surrounding towns, because of original playgrounds, interesting and comfortable places for rest, and a colourful and playing fountain. Litewski Square brings many generations together in one place, attracting both residents and tourists of all ages. Among the objections to the current form of the square is the significant reduction in greenery and biologically active area, compared to the time before revitalisation.

\section{Results of the analysis according to Jan Gehl's criteria - chosen elements}

During analysis with the aspects assigned to a given criterion Case Study Area 1 received 11 out of 12 possible points.

\section{Protection (2 points)}

Litewski Square is completely excluded from vehicular traffic and has restrictions for cyclists. It is a space that flows smoothly into the pedestrian route running through the Old Town. Numerous city surveillance cameras, frequent patrols of the city guard and police, and above all the presence of many participants make this space safe. The problem is the lack of protection against unpleasant sensory experiences, caused by significant felling of large trees and the lack of other forms of roofing.

\section{Comfort (6 points)}

The new surface of the square made of smooth granite slabs and wood is comfortable to walk on. All development elements are highly visible. The square has several distinctive defined spots for staying and objects enhancing to stand next to. The large number of diverse seating areas, giving the opportunity to observe the various activities of other users of the space are an advantage. In addition to its permanent recreational functions, the square is a venue for seasonal events.

\section{Enjoyment (3 points)}

The square is surrounded by attractive historical buildings, among which public functions dominate. In the northern part of the square, left-over old trees give the opportunity for enjoying positive aspects of climate. Aesthetic quality and fine detailing of small architecture and plants give positive sensory experiences.

\section{Study Area 2: Intimate inner-city square - Square at the Cultural Centre}

The space in question is located in the city centre in the vicinity of the renovated building of the Cultural Centre (CK) in Peowiaków Street, approximately $100 \mathrm{~m}$ from Litewski Square. The space functions under several names: Central Playground, Lech Kaczyński Square (directly next to the CK building), and Children of Pahiatua Square. It is a small green square formed in place of the former monastery garden. What remains of it is an arrangement of old trees [Fig. 3].

The square has several zones: a green recreational zone with tall trees and benches, a separate playground and gym, and a paved area around the historic shrine of Christ the Sorrowful, located at the main entrance to the Cultural Centre building. All these zones are linked by permanent or temporary art elements. They are very diverse: from the already mentioned historic baroque chapel, through the martyrological monument to 
Sybirak Mother, the concrete cubes which gain a different appearance every year, numerous temporary sculptural installations, to the mural on the wall marking the northern border of the square. The so called Central Playground uses different textures and colours of surfaces for walking, roller skating, skateboarding or cycling, interspersed with lawn strips and benches. The extreme part of the square features a sculpture in the form of a huge red hand embracing a tree trunk (authors: K. R. Filipowski, P. Pawluk, K. Czosnyk, T. Wojna, 2018). A year later, artistic installations by Anna and Irena Nawrot "Nests" appeared on the trees around the CK. The friendly public space of the square, its intimate character, different from that of Litewski Square, attracts residents, providing an attractive place for children, young people as well as the elderly. At the same time, the wooded part of the square is often visited by alcoholics and the homeless.

Among the public spaces surveyed, the square is characterized by differences in public perception. The users perceive it as indifferent, negative (boredom, dislike) as well as arousing interest. The degree of the latter emotion is the highest in relation to all surveyed spaces, which is connected with its greatest changeability, caused by artistic activities taking place in this space. An example is the installation by K. Stańczak "Background of Events" [Fig. 3 a]. The art installation was realized in 2018 as part of the $10^{\text {th }}$ Open City Art in Public Space Festival 2018. The work referred to architect Oscar Hansen's postulate to organize architecture and public space according to the Open Form. It is a loose reference to Katarzyna Kobro's Spatial Form IV from 1929. Its integral and inseparable part are, among others, skaters who break the stability of the artistic form with real movement.

a)

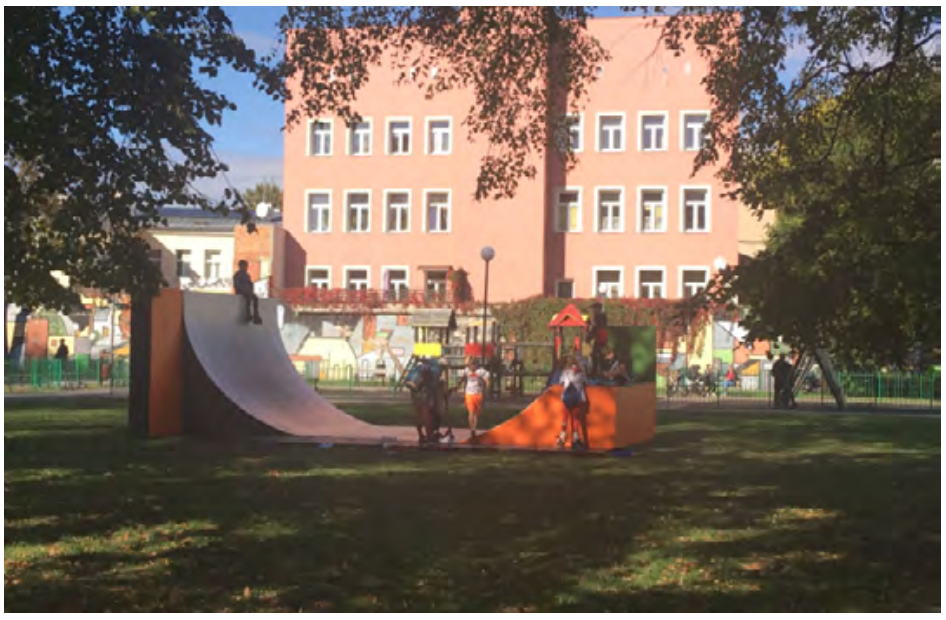

b)

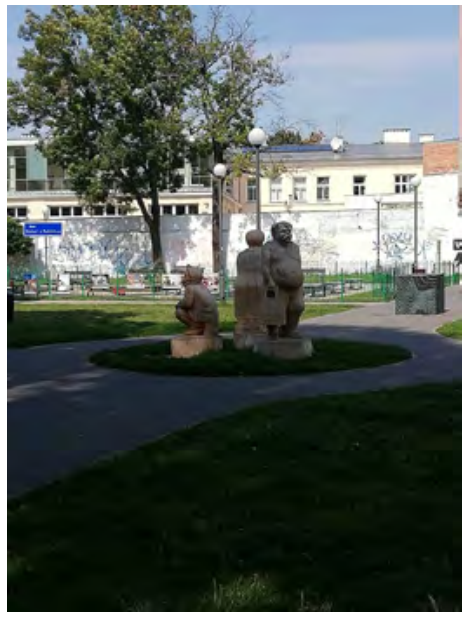

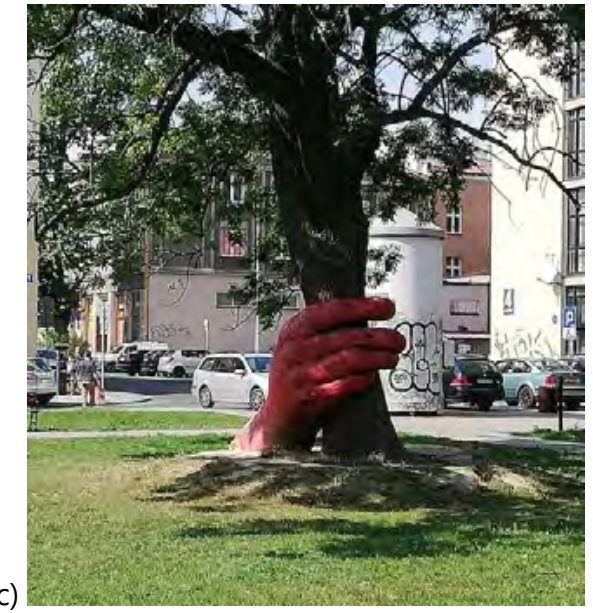

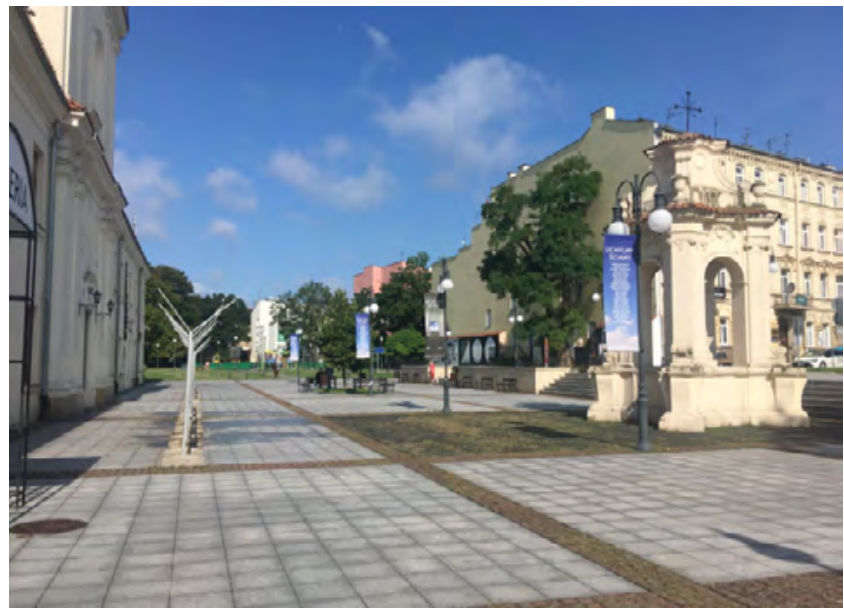

Fig. 3. Characteristic elements of Square at the Cultural Centre. (a), (b), (c) - temporary art installations, (d)- Lech Kaczyński Square 


\section{Results of the analysis according to Jan Gehl's criteria - chosen elements}

During analysis with the aspects assigned to a given criterion Case Study Area 2 received 8 out of 12 possible points.

\section{Protection (1 point)}

The square is isolated from vehicular traffic. Due to the presence of alcohol drinkers and homeless people, the sense of personal safety may be low. Outside the crowns of tall trees, there is a lack of elements to protect from the sun or rain.

\section{Comfort (5.5 points)}

The varied nature of the square means that the area offers a variety of attractions for users, but there is a lack of attractions during the winter period.

\section{Enjoyment (1.5 points)}

The buildings surrounding the square are of varying public accessibility and architectural quality. The aesthetics of the landscaping elements leave much to be desired, but they are functional.

\section{Study Area 3: public space accompanying the commercial function - shopping mall roof}

The arguments in favour of the positive impact of nature on people have contributed to the increasing use of green roofs with plants by architects, which are often the only alternative to introduce a bit of greenery to densely built-up cities. They are also an appropriate solution from the point of view of improving the urban microclimate and retention of rainwater. One such example is the Vivo shopping centre building in Lublin (designed by B. Stelmach and Partners). The building combines the maximum use of investment opportunities for a large-scale commercial building with the need to protect the panoramic view of the Old Town hill, and ecological aspects, which involved introducing the development into green areas. When designing this building, the architects took into account the context of cultural heritage, surrounding nature and location - in the city centre with a view of Lublin Castle. In this case, the green roof resulted primarily from conservation conditions, but became an attractive public space [Fig. 4].

The partially designed public green roof with paths and benches proved to be an effective way to attract residents. It allows people to meet in the outdoor green space and enjoy both the distant views and the interestingly selected plants on the roof itself. In the summer, the space is enriched by additional functional attractions: a beach, cafés, a playground or a summer cinema. The flat roof has become part of the system of urban public spaces, even though it is part of a private, commercial building.

\section{Results of the analysis according to Jan Gehl's criteria - chosen elements}

During analysis with the aspects assigned to a given criterion Case Study Area 3 received 4.5 out of 12 possible points.

\section{Protection (1 point)}

The roof is accessible both from inside the shopping mall building and from the outside, with both access routes periodically closed by the manager. In case of unfavourable weather conditions the area is not well suited for outdoor activities. 


\section{Comfort (2 points)}

The space is attractive mainly because of the panoramic views of the city. In summer the recreational offer is enriched by temporary attractions, which increases the number of visitors. However, the existing benches are insufficient for a larger number of users. In autumn and winter the terrace is closed.

\section{Enjoyment (1.5 points)}

The scale of the building does not allow this space to be defined by its attractive edges. The most important aesthetic experiences are the distant views and the high quality of the plant selection and landscaping elements.

a)

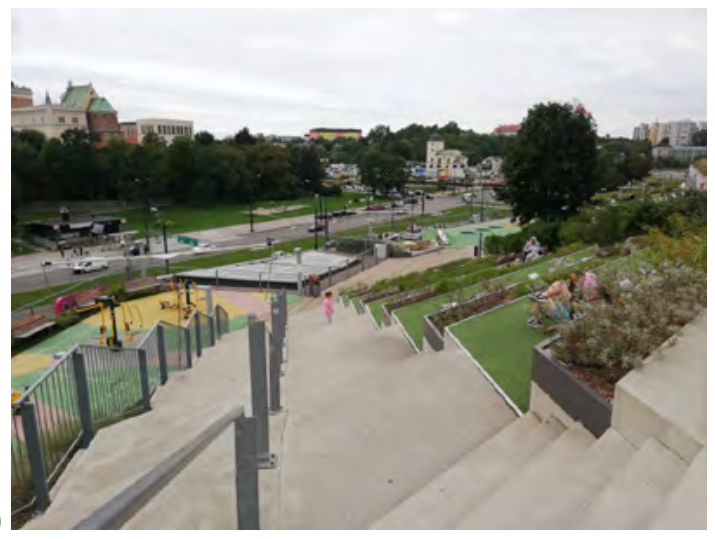

C)

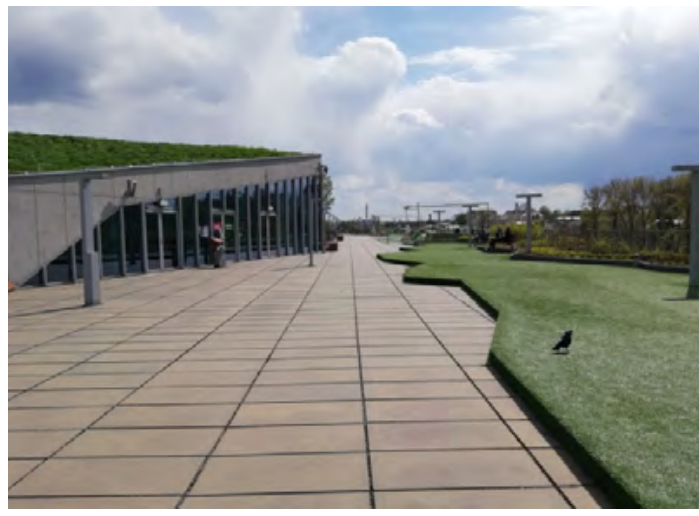

b)

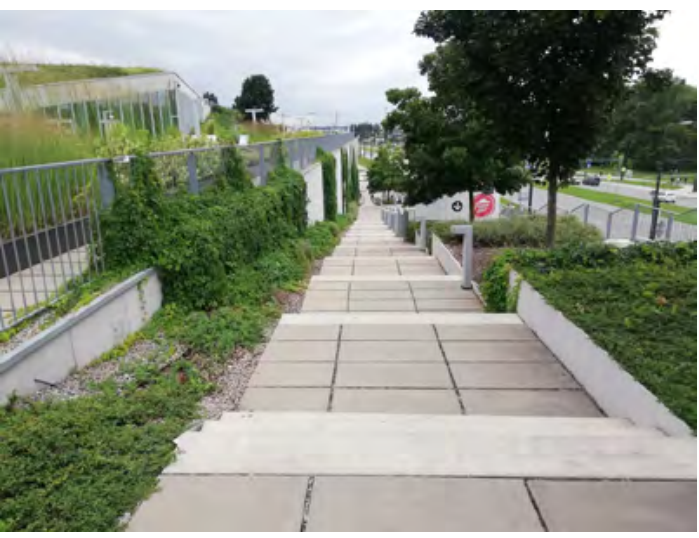

d)

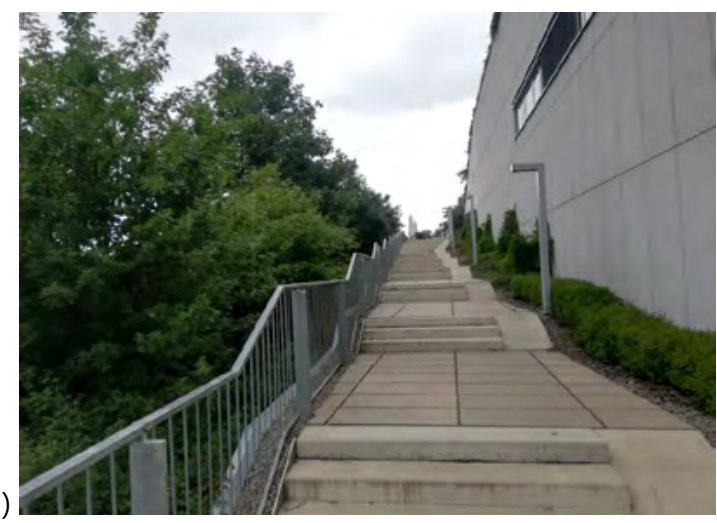

Fig. 4. Characteristic elements Galeria Vivo roof - public function on commercial building, (a) -view in the direction of the castle hill, (b) - main and side stairs form the ground level to the roof, (c), (d) - upper terraces

\section{Study Area 4 public space accompanying the cultural function - the roof of the Meeting of Cultures Centre "Sky Terraces"}

The roof of the Meeting of Cultures Centre in Lublin is another example of a new public space using elements of the natural environment. The modern edifice of the building was created on the basis of the so-called 'Theatre under Construction' - a structure that had remained unfinished since the late 1970s. The CSK building was put into use in 2014, but the increase in the popularity of the public space on the roof observed over the last 5 years is related to the development of vegetation. The Meeting of Cultures Centre, by design, is intended to be a place where different cultures coexist, thus upholding Lublin's tradition as a city on the borderline of cultures. The ECC is intended to be a place of dialogue and meeting place for cultural and intellectual matters in 
Central and Eastern Europe [44]. In this context, the "Sky Terraces" offer the possibility of admiring the panorama of Lublin's downtown for free, with the most important parts of the city and its multicultural tradition visible.

The CSK building is located in the city centre opposite the oldest city park - the Saxon Garden. Its location creates a pretext for an architectural statement different from the standard one, while in the immediate vicinity a sequence of public spaces of different scale and character is created: the square in front of the front façade is a multifunctional "stage" and auditorium at the same time. The façade on this side of the building is clad with glass with a very low iron oxide content, which ensures high light transmission. The glass used in the construction provides greater light transmission, thus creating brighter interiors, protecting against heat loss and enabling complete privacy.

The accessible areas of the roof of the CSK building are located on two levels: +4 housing a café, a nature trail and an urban apiary, and +5 being the viewing terrace. Access to these spaces is possible during the opening hours of the institution and is provided by lifts from inside the building. Both levels offer spectacular views of the surrounding city centre. On the roof, there are glass tunnels where one can walk around admiring native plant species typical of the Lublin region, shrubs and fruit trees planted there. On the roof of the building there is a summer educational path dedicated to ecology and nature. The translucency of the glass and the substrate (steel grids) means that not every user feels comfortable in this space. Through the use of individual technical solutions, a sense of lightness and naturalness has been achieved in the context of the urban fabric. By combining the contemporary possibilities of glass with elements of nature, it becomes authentically present in the urban space and in the consciousness of its inhabitants [Fig. 5].

a)

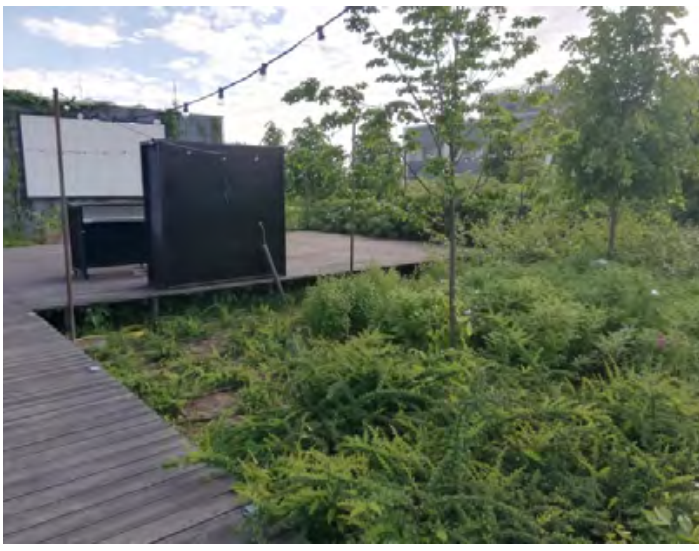

C)

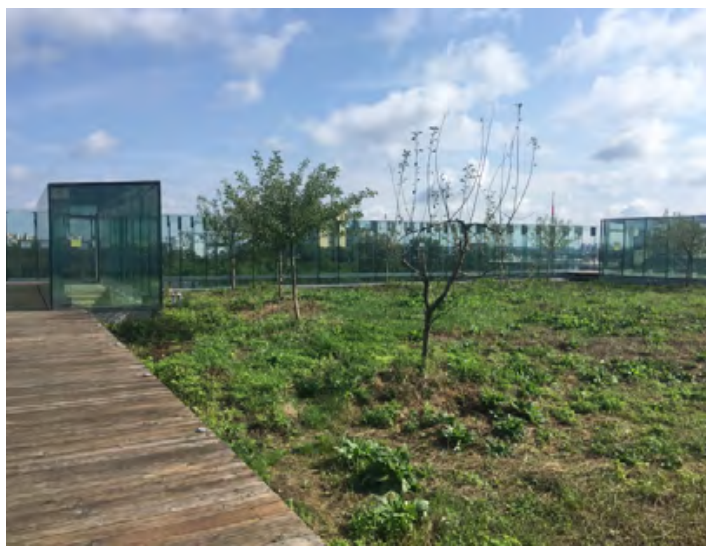

b)

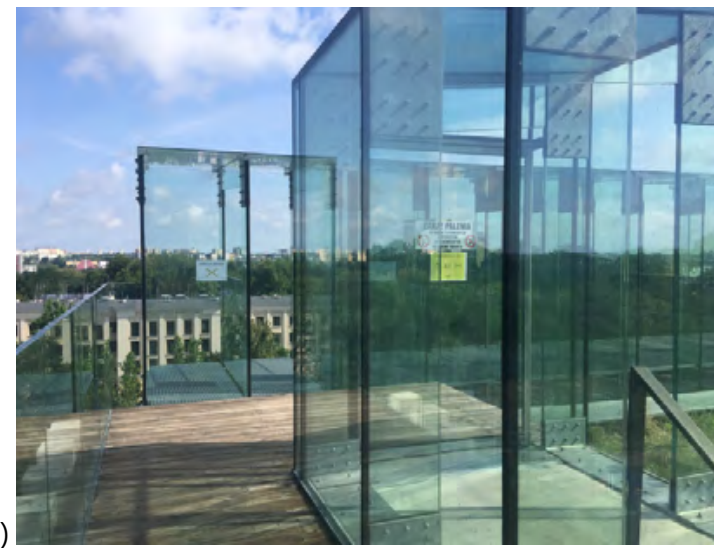

d)

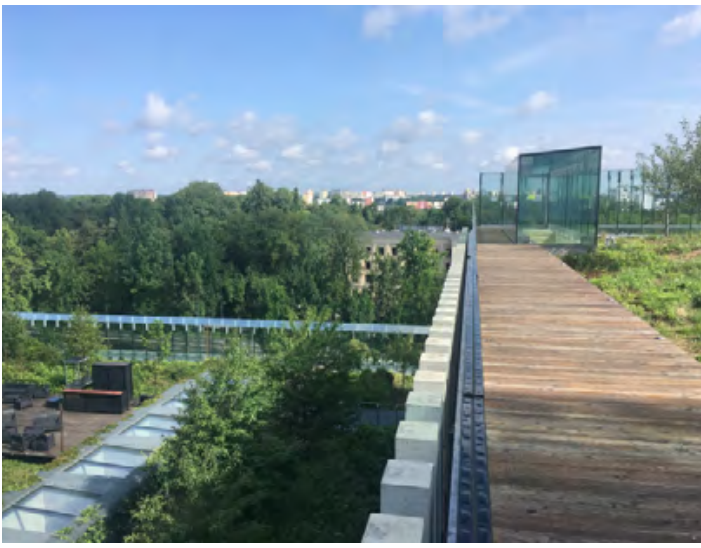

Fig. 5. Characteristic elements of the roof of the Meeting of Cultures Centre "Sky Terraces" (a) - arrangement for temporary attraction, (b) - entrances and glass tunnels, (c) - main walking path, (d) - general view

Green roofs, which are often a rational necessity in densely built-up urban environments, can become fully-fledged public spaces. The examples studied in Lublin show that their popularity is determined mainly by 
accessibility and the quality of the view links. In the case of Lublin, publicly accessible green roofs are still rare, but both legal conditions and the growing awareness of designers and investors give hope for their wider use. If properly designed, they can become valuable natural and social spaces: they reduce the level of pollution in the environment, protect against noise, improve air quality and microclimate, which is important for the health of residents. Thanks to such solutions, cities gain cleaner air and their inhabitants additional areas for recreation.

\section{Results of the analysis according to Jan Gehl's criteria - chosen elements}

During analysis with the aspects assigned to a given criterion Case Study Area 4 received 5 out of 12 possible points.

\section{Protection (2 points)}

The roof is accessible only inside the building by lifts. Users are constantly "accompanied" by surveillance cameras. In case of unfavourable weather conditions the area is not suitable for staying.

\section{Comfort (2.5 points)}

The space is attractive mainly because of the panoramic views of the city. Many people find it uncomfortable to move inside the glass tunnels with the transparent floor. The traffic surface is not conducive to wearing smart shoes. There is a lack of places to sit and stop. Most of the temporary attractions have to be paid for. The terrace is closed during autumn and winter.

\section{Enjoyment (0.5 points)}

The scale of the building does not allow this space to be defined by attractive edges. Distant views and high quality plant selection are the most important aesthetic experiences. There is a lack of small architectural elements, although the architecture of the building itself is outstanding.

\section{Stud Area 5 - city park. People's Park (Park Ludowy)}

The People's Park is part of a system of publicly accessible green areas associated with the valley of the Bystrzyca River. In the interwar period, a horse racing track was created adjacent to the popular urban river beach, and areas of the Bystrzyca meadows in the vicinity of the city centre were identified as potential sites for fairs, exhibitions and mass recreation. In the post-war period, plans were continued by locating sports facilities and planning a system of parks of peri-urban importance, of which only Park Ludowy was realised. The flood hazard and periodic flooding of the wide valley prevented full use of the recreational potential of the meadows until 1976, when the construction of the Zemborzycki Reservoir was completed.

The People's Park, covering an area of about 28.5 hectares, was created between 1950 and 1957 on wet meadows on the Bystrzyca River. Its composition refers to baroque solutions, which was a popular solution during the Socialist Realism. A characteristic element of the layout was an axis ending in an amphitheatre.

The construction of the park was connected with the new political situation - emphasising the idea of the People's Republic of Poland through the participation of residents in the construction as part of community work. At that time the attractions included an airplane-café, an amphitheatre and a traffic town. The park functioned quite well until the $1980 \mathrm{~s}$, when it began to deteriorate. At that time, the trees began to die due to the waterlogged ground, excessive growth of low plants, which, combined with the cessation of upkeeping works, soon brought the place to a state of extreme neglect. The trees were also badly affected by the vicinity of the Lublin Sugar Refinery, which stored sugar beet flotation waste in the park. In the 1990s, a permanent funfair operated in the park, but this did not improve the public perception of the People's Park, which was regarded as neglected and dangerous.

At the beginning of the $21^{\text {st }}$ century, in the southern part of the park, the hall of the Lublin International Fair (now Targi Lublin S.A.) was located, which introduced a new function to the area. 
In 2011, the expansion of the trade fair complex began. The new hall $\left(8,000 \mathrm{~m}^{2}\right)$, the construction of which took up a large part of the park, blurred the parks original composition. Plans to build an educational and scientific centre called "Eksploratorium" in the People's Park were not realised by the city. In 2012, in response to the gradual development of the park, a social concept for the development of the People's Park was created, which indicated the current needs of users and showed examples of solutions. The concept was prepared in a public consultation process that included a series of open meetings and workshops, and designs made by students of Catholic University of Lublin and University of Life Sciences in Lublin, presented during a public discussion. In 2015, a social concept for the revitalization of the park was created, which was taken into account by the designers. The construction project itself was also subject to public consultation. The current shape of the park is the result of revitalization works that took place between 2019 and 2020.

Before the renewal works, the People's Park was included in the group of "semi-open parks (share of tall vegetation from 25 to 50\%), in which the ratio of tall and medium vegetation is balanced with meadow and grassland areas" [45]. Before revitalization, the area was rated negatively by users due to dilapidated fixtures, neglected greenery and lack of attractions.

The revitalized park was opened in XII 2020, but interest in it peaked after the removal of sanitary restrictions in May 2021.

a)

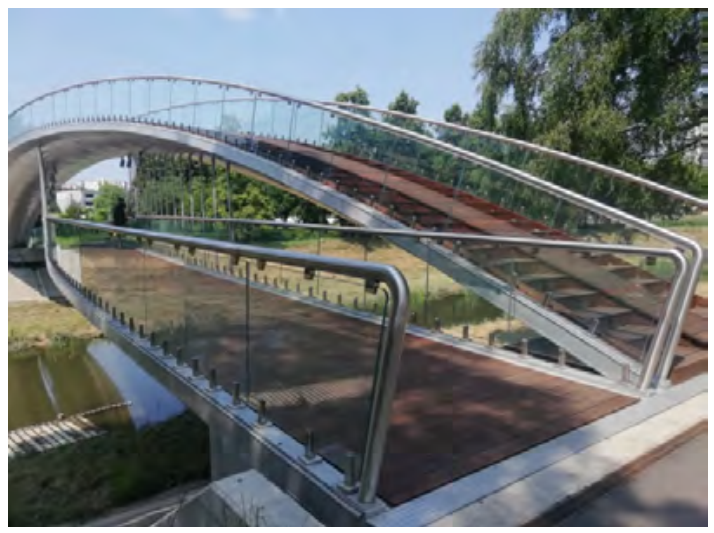

C)

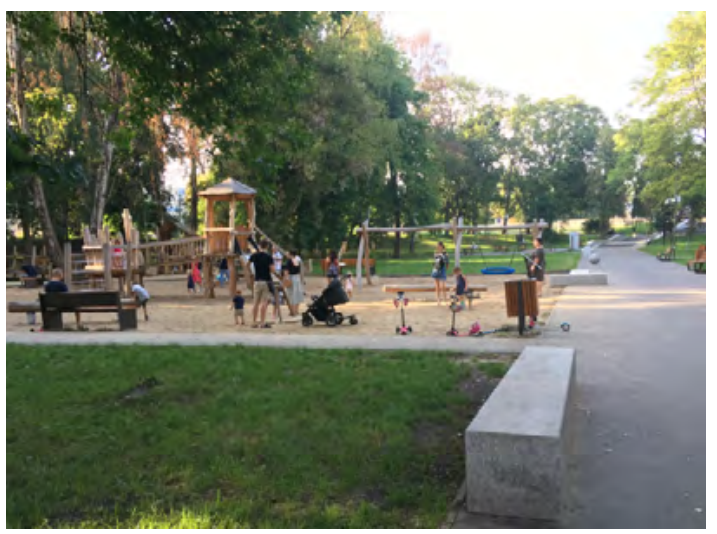

b)

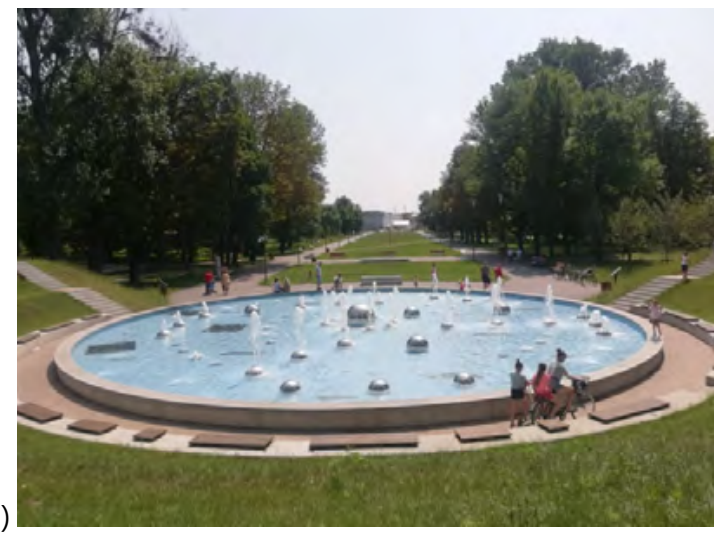

d)

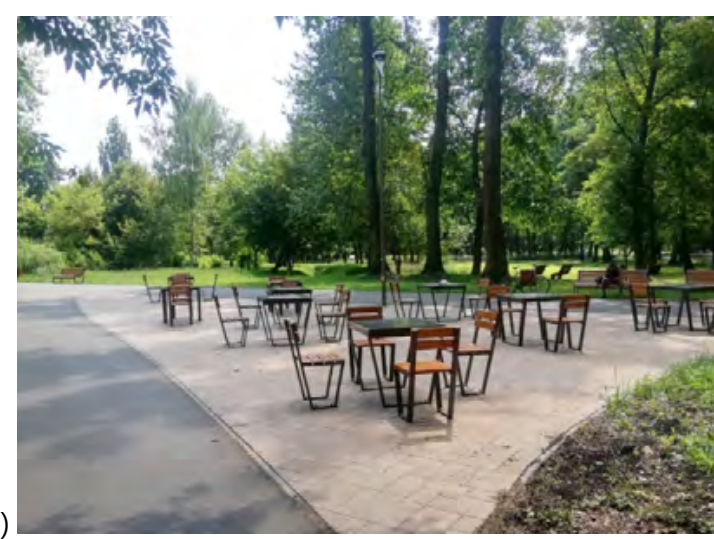

Fig. 6. Characteristic elements of the the People's Park (a) - new pedestrian and bicycle bridge, (b) - fountain and the main composition axis, (c) - one of the playgrounds, (d) - chess area

The revitalization of these areas has made it possible to create a place for active recreation, providing a wide range of recreational opportunities for different age groups [Fig. 6]. The redevelopment included comprehensive greenery management, the creation of gardens and nature trails, a rest area, playgrounds, a gym and walking and cycling routes. In order to maintain harmony with the surroundings, the playgrounds were made of wood. The equipment in the physical activity zone is designed for different groups of users, regardless of experience and level of advancement. In addition, the area is equipped with volleyball posts and nets, 
and a separate area for playing boules. All recreational facilities and paths are accompanied by visual information elements in the form of boards. A didactic water garden in the form of an amphitheatre with stands and a basin has been introduced in the central part of the park. The greenery surrounding the garden has been supplemented with elements of small architecture, which promote calm and contemplation. There is a path of the processes of passing, which consists of plants in various stages of life. Another element accompanying the walking alleys is a didactic philosophical path consisting of specially designed free-standing granite forms which may serve as seats or as decorative sculptures. Their location also favours their use by roller-skaters and cyclists as terrain obstacles. Due to poor ground conditions, a drainage system was built under a large part of the area: rainwater is drained into a drainage ditch, from where it is directed to a pumping station and a river.

During the redevelopment, the previously existing trees were left in place and new trees, shrubs, ivies and ornamental grasses were planted. The didactic garden was planted with aquatic plants typical of this region of the country. Old trees, trunks and broken boughs left behind are intertwined with newly planted plants to form exhibits of plants in various stages of life. The greenery in the park area is varied and includes both densely wooded areas and open spaces. The highest density of trees is found in the northern and north-western part of the park, where there is a large number of self-seeders, forming dense and unplanned clusters.

\section{Results of the analysis according to Jan Gehl's criteria}

During analysis with the aspects assigned to a given criterion Case Study Area 5 received 11 out of 12 possible points.

\section{Protection (2.5 points)}

The high number of users and the discreetly placed monitoring and lighting promote a feeling of security.

\section{Comfort (5.5 points)}

High saturation of attractions is conducive to both active and passive leisure. The traffic surface is very comfortable. There is no shortage of places to sit.

\section{Enjoyment (3 points)}

High quality solutions of landscaping elements. Accessibility to natural water (river) as well as in the fountain are the greatest values

\section{General Results}

Studies of spaces according to Jan Gehl's criteria indicate that most of them are fulfilled in the case of Litewski Square and Ludowy Park - spaces whose construction was proceeded by public debates, contests and media publicity. A relatively high assessment was given to the square next to the $C K$, which arouses the most controversy in the assessment of users' perception. The public spaces created on the roofs scored very poorly according to the Jan Gehl criteria, receiving less than half of the possible points. In the opinion of the authors, this shows that this method is not suitable for the assessment of spaces such as green roofs, as these spaces were ranked relatively high in the user evaluation survey [Fig. 7]. Perhaps a different tool should be developed for the assessment of green roofs, as the user assessments show that they can compete with squares and parks, i.e. traditionally shaped public spaces.

The results of the survey indicate that the most popular public space for leisure activities in Lublin is the People' Park (36\%), which has a fairly large green area, deckchairs and benches for relaxation, playgrounds for children and young people, a gym and creative facilities. It was followed by the roof of the Galeria Vivo (27\%), Litewski Square (16\%), the roof of the Meeting of Cultures Centre (15\%), and the square in front of the Cultural Centre (6\%) [Fig. 7].When choosing a space, respondents were mainly guided by "the atmosphere of the place" (30\%), "equipped with small architectural elements" (22\%), high aesthetic value of the space (21\%), and "the atmosphere of the place" (21\%), "high aesthetic value of the space" (12\%) "condition of greenery" (11\%) 
and provision of elements for active recreation and play (11\%). The subjective assessment of these three criteria makes it possible to underline the importance of greenery, aesthetics and the quality of the landscaping elements in the overall assessment of the space, while at the same time being translated into objective figures.

Table 2. The results of spatial analysis with the use of Jan Gehl's 12 criteria for the quality of livable public spaces

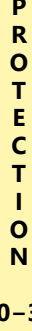

$0-3$

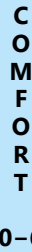

$0-6$

E

N

o

Y

M

E

0-3

Elements analyzed:

-3

\section{Case Study 1 \\ Case Study 2 \\ Case Study 3 \\ Case Study 4 \\ Case Study 5}

Elements analyzed:

Case Study 1
Case Study 2
Case Study 3
Case Study 4
Case Study 5

\section{Elements analyzed:}

Case Study 1

Case Study 2

Case Study 3

Case Study 4

Case Study 5

\section{Elements analyzed:}

$$
\begin{aligned}
& \text { Case Study } 1 \\
& \hline \text { Case Study } 2 \\
& \hline \text { Case Study } 3 \\
& \hline \text { Case Study } 4 \\
& \hline \text { Case Study } 5
\end{aligned}
$$

Protection against vehicular traffic (0-1):

Traffic accidents;

Pollution fume, noise; Visibility

Possibilities for Walking
(0-1):
Room for walking; Accessibility
to key areas; Interesting
façades;
No obstacles;
Quality surfaces

Protection against crime\&violence (perceived safety) (0-1):

Lively/Active

Street life

Passive Surveillance

Overlapping functions in space and time

\author{
Protection against \\ unpleasant sensory \\ experiences $(0-1)$ : \\ Wind/Draft \\ Rain/Snow \\ Cold/Heat \\ Pollution \\ Dust/Glare/Noise
}

Possibilities for Standing/ Staying (0-1):

Attractive edges - "Edge effect";

Defined spots for staying; Objects to lean against or stand next to

0.5
0
0
0
0.5

Possibilities for Sitting (0-1):

Zones for sitting;

Maximize advantages -

pleasant views, people

watching;

Benches for resting

\section{Possibilities to See (0-0.5):}

Distances to objects;

Unhindered views;

Interesting views;

Lightening when dark

Possibilities for hearing talking (0-0.5):

Low ambient noise level; Sitting arrangements conducive to communicating

\section{Possibilities for Play /}

Recreation / Interaction (0-1):

Allowing for physical activity, play, interaction and entertainment:

Temporary activities (markets, festivals, exhibitions, etc.); Optional activities (resulting, meeting, social interaction)

\section{Day and Night activity} (0-0.5):

24 hour city;

Variety of functions throughout the day;

Light in the windows

(residences);

Mixed-use;

Lighting in human scale

Seasonal activities (0-0.5):

Seasonal activities;

Extra protection from unpleasant climatic conditions Lightning
Possibilities for enjoying positive aspects of climate (0-1):

Sun/shade

Warmth/coolness Breeze/Ventilation

1
0.5
0.5
0.5
0.5 \\ 1

Aesthetic quality/positive sensory experiences (0-1): Quality design and fine detailing; Views/ vistas; Trees, plants, water
Dimensioning of buildings and spaces in observance of the human dimensions related to behavior

1
0.5

$$
1
$$




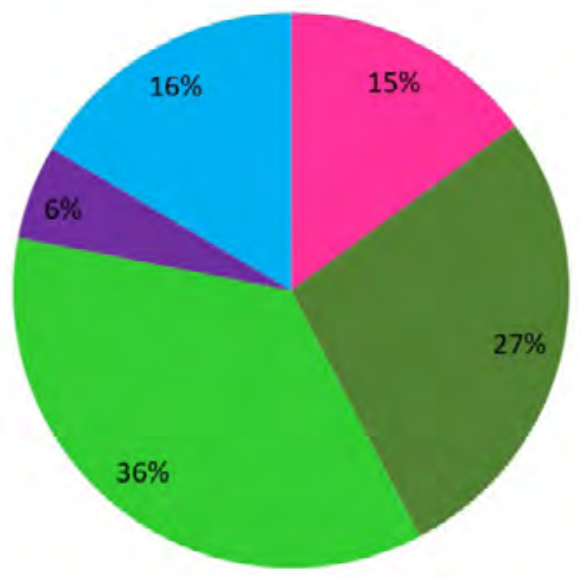

\author{
Litewski Square \\ Equare in front of the Cultural \\ Centre \\ Eoof of Galeria Vivo \\ E Roof of the Meeting of \\ Cultures Centre \\ - People' Park
}

Fig. 7. Diagram illustrating the user's perception of the selected spaces based on the questionnare

The most subjective to define, and at the same time crucial for the assessment of the quality of public spaces, was their atmosphere. Respondents were asked to indicate the emotions accompanying their stay in the surveyed public spaces. The choice was up to 3 emotions/feelings, both positive, negative and ambivalent. The majority of the surveyed spaces were dominated by positive emotions such as: pleasure, satisfaction, admiration, curiosity, and calmness. Among the negative ones the respondents could indicate: anger, irritation, confusion, dislike, boredom. Additionally, it was possible to indicate indifference. Each of the surveyed spaces was tested for the occurrence of these emotions. It should be noted that the occurrence of positive emotions coincides with the high rating of atmosphere as one of the criteria for the subjective evaluation of the space. Among the emotions, pleasure and satisfaction dominated. The greatest diversity of emotions accompanying the perception of space was indicated by respondents in the case of Square at the Cultural Center. Among the emotions accompanying its reception, the following were indicated: indifference (20\%), aversion (16\%), satisfaction (18\%), pleasure (15.5\%), boredom (13.5\%) curiosity (11\%), admiration (5\%), peace (2\%) [Fig. 8].

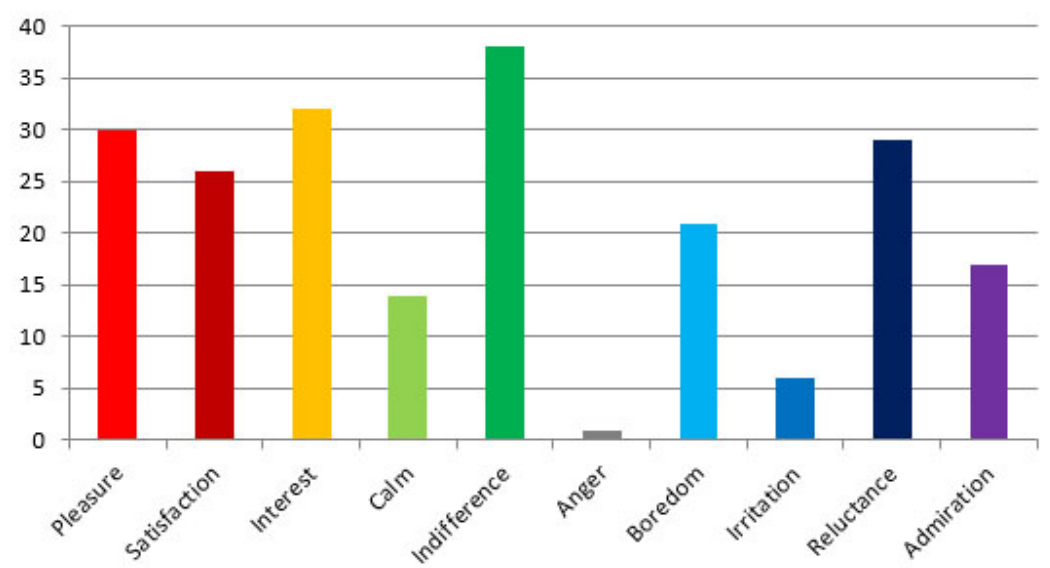

Fig. 8. Diagram illustrating the diversity of emotions accompanying the perception of space Square at the Cultural Center

The respondents were asked to indicate up to 3 elements which determine the attractiveness of the evaluated public spaces or have an influence on its enhancement. The most frequently indicated elements were the presence of greenery 115 out of 150 responses, outdoor cinema 100 out of 150 responses, elements of small architecture 84 out of 150 responses, places for rest 81 out of 150 responses, lighting 86 out of 150 responses, community gardens 76 out of 150 responses, temporary exhibitions 55 out of 150 responses and elements of art 41 out of 150 responses [Fig. 9]. Obtaining such a high rating for the idea of an outdoor cinema may be relevant to the current post Covid-19 situation. 


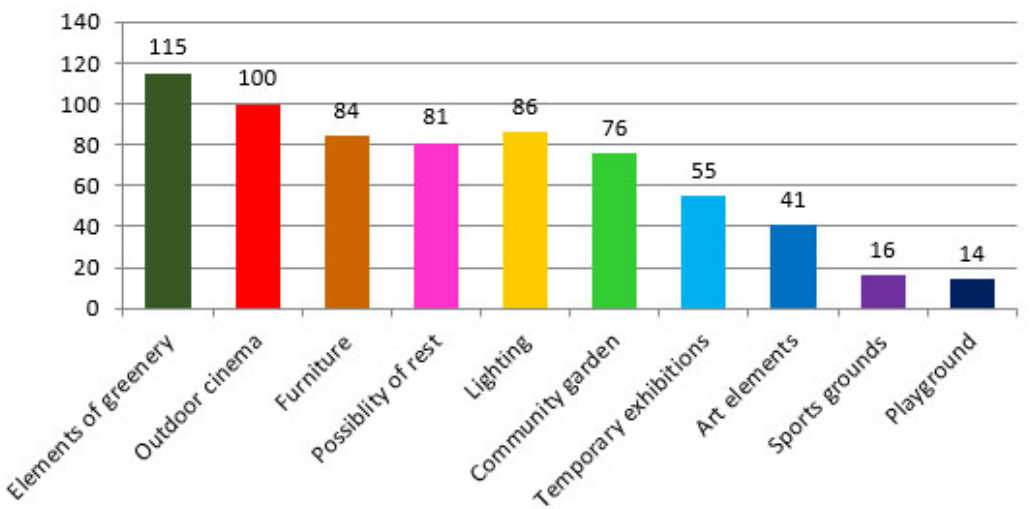

Fig. 9. Diagram illustrating the most desirable elements overengineering public space

The lowest ranked space among the proposed spaces was the Case Study 2 - square at the Cultural Centre (CK) (33\%), where a large number of respondents did not choose this space because of the lack of a sense of security (18\%), the poor aesthetics of the space (15\%) and because of not well-kept greenery (28\%). These features were also the most frequently chosen answers when indicating the weakest spaces. The most common emotions experienced while staying in the least chosen spaces are indifference, aversion, boredom and irritation. In turn, the most frequently experienced emotions when staying in well-designed spaces are pleasure, delight, peace and contentment.

The majority of respondents (92\%) felt that elements of art in the urban space increase the attractiveness of the place and play an important role in social life. When it comes to the reception of street art, curiosity and admiration were the most frequently chosen answers in terms of the type of emotions evoked [Fig. 10]. As many as (87\%) respondents believe that elements of art can play a significant role in the revitalisation of urban spaces. Most respondents (88\%) agreed that art is able to satisfy human needs not only in terms of aesthetic and visual, but also psychological and social aspects.

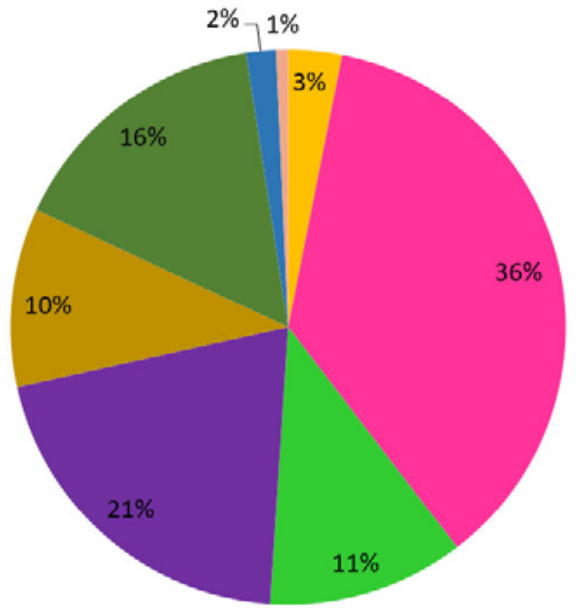

mey enrich the landscape in which they are located

- They intrigue me, stimulate my creativity

- They generate positive emotions and attract the attention

- They move my imagination

- They have a soothing and relaxing effect

- I don't pay attention to them

w They are not important

n' They annoy me
Fig. 10. Diagram illustrating the importance of art elements in public space

The data analysis of the survey results shows that only a part of the analyzed public spaces in Lublin selected for the survey fulfil the functions expected by their users. Only those spaces which contain a lot of greenery, places for play and rest, and elements of art are frequently visited. the city's public spaces, which were selected for the study, fulfil the functions expected of them by their users. only those spaces which contain a lot of greenery, places for play and relaxation as well as elements of art are frequently visited.

The People' s Park, which was voted the best public space by the respondents, is a space where users have to go with purpose (it's not a space that one passes by). Its location in a sequence of recreational and sports areas along the Bystrzyca valley is conducive to active leisure. To a large extent, this space meets the basic needs of its users, as it contains comfortable places for relaxation, opportunities for gymnastics, interesting 
places for children to play, numerous ramps and paths for scooters and roller skates, and a separate area for playing chess and boules. It is probably the first place in Lublin that can provide various attractions at the same time, regardless of the age of users.

In spite of the imperfections of the selected spaces in Lublin, they are very often visited by the inhabitants who often struggle with the lack of green areas in the closest vicinity of their residence. The research carried out, on the one hand, shows what is most interesting, what attracts people and encourages them to visit a given space. On the other hand, it reveals certain imperfections and shortcomings which influence the perception and frequency of visiting a given place. Among the spaces selected for the study, each of them has certain shortcomings and imperfections, as some lack greenery, others comfortable places for relaxation, and still others creative-artistic activities. All this influences the positive or negative perception of a given space, which is reflected in the number of visitors. Man feels good among greenery, in a place where he can rest comfortably and calmly. On the other hand he constantly needs contact with other people, in a place which is aesthetically pleasing, functional, where he feels safe and which meets his expectations also from a psychological point of view.

The needs of society are constantly changing, and therefore public spaces should not be regarded as finished, but should be open to the possibility of making changes and experimenting with the needs of the residents [46].

\section{Conclusions}

The design of high quality and attractive spaces is an important element of urban renewal. This type of activity leads to an increase in the quality of life, creates image-attractive cities and attracts residents and tourists. In the latest realizations of public spaces in Lublin, the influence of the design methodology of prof. Jan Gehl is noticeable. To the greatest extent it concerns the realization of the People's Park, the design of which was created in close cooperation with city activists and the process of social participation was really real. This area was rated highest by users and became new landmark in the city.

Livable urban public spaces should be diverse, original, safe and heterogeneous, so as to provide comfort and recreation for the inhabitants and all users. The combination of elements of nature, art and good quality landscaping, creates an inextricable link with the past and influences their development. Very often livable public spaces are the most characteristic urban spaces, which due to the functions they perform, and their identity become landmarks and therefore eagerly visited by residents and tourists.

The analysis presented reveals that public space in cities is not only an area where residents and tourists can potentially meet, but is much more than that, as it has a direct impact on lifestyles. Undoubtedly, well-designed public spaces, where various social activities take place, influence the social character of the city and its inhabitants [47].

In view of the emergence of new forms of public space such as green roofs, there is a need to develop a methodology for their assessment in terms of quality criteria, as the classical approaches do not take into consideration their specific features. Green roofs or other spaces often associated with commercial facilities can be attractive public spaces and competitive with traditional squares or parks.

\section{References}

[1] 2014 Year of Jan Gehl in Lublin. Available online: http://yearofjangehl.ulublin.eu/ (accessed on 20072021 ).

[2] Göçer Ö., Göçer K., Başol A.M., Kıraç M.F., Özbil A., Bakovic M., Siddiqui F.P., Özcan B., Introduction of a spatio-temporal mapping based POE method for outdoor spaces: Suburban university campus as a case study, Building and Environment 2018, Volume 145, pp. 125-139.

[3] Gehl People, Available online: https://gehlpeople.com/people/, The Public Life Diversity Toolkit 2.0 (accessed on 05 05 2021).

[4] Gehl J., Life between buildings: Using public space.; Island Press: London 1971.

[5] Gehl J., Gemzoe L., Kirknaes S., Søndergaard B.S., New City Life, The Danish Architectural Press, 2006, further developed: Gehl Architects - Urban Quality Consultants, 2009. 
[6] Niebylski M., Raport z badań ankietowych, Lublin 2021, Available online: https://lublin.eu/gfx/lublin/userfiles/_public/ aktualnosci/2020/2021/diagnoza_lublin_2030__raport_z_badan_ankietowych.pdf.

[7] Maleszyk P., Czego potrzebuje Lublin? Raport z badania, jakości życia w dzielnicach Lublina, Raport o stanie miasta za 2019, opracowanie Urząd Miasta Lublina.; UM Lublin 2018. Available online: https://depot.ceon.pl/bitstream/handle/12 3456789/16547/\%5B2018\%5D_Czego_potrzebuje_Lublin_\%5Braport_dzielnicowy\%5D-skompresowany.pdf?sequence=1 (accessed on 2508 2018).

[8] Lorens P., Tematyzacja przestrzeni publicznej, jako wyraz dywersyfikacji struktury urbanistycznej miasta doby globalizacji, In Percepcja współczesnej przestrzeni miejskiej, Madurowicz M., Eds.: Wydział Geografii i Studiów Regionalnych Uniwersytetu Warszawskiego, Warszawa 2007, pp. 83-92.

[9] Hładkiewicz W., Koncepcja przestrzeni publicznej w teorii krytycznej Jürgena Habermasa, In Sfera publiczna. Kondycja - przejawy - przemiany.; Hudzik J.P., Woźniak W. Eds., Wydawnictwo Uniwersytetu Marii Curie-Skłodowskiej, Poland 2006, pp. $143-148$.

[10] Cegłowska A., Matykowski R., Przestrzenie publiczne i ich znaczenie w dużym mieście: przypadek Poznania, Studia Miejskie, 2, Poland 2010, pp. 243-256.

[11] Markowski T., Przestrzeń publiczna wobec procesu metropolizacji, Urbanista, 7 (51), 2007, pp. 10-15.

[12] Bierwiaczonek K., Nawrocki T., Teoretyczne spojrzenie na przestrzeń publicznq, In Rynki, małe i cmentarze. Przestrzeń publiczna miast śląskich w ujęciu socjologicznym, Bierwiaczonek K., Lewicka B., Nawrocki T. Eds., Nomos, Kraków 2018.

[13] Trojanowska M., Urban design and therapeutic landscapes. Evolving theme, Budownictwo i Architektura 2021, 20(1), pp. 117-140. DOI: 10.35784/bud-arch.1987.

[14] Carmona M., de Magalhães C., Hammond L. Eds.; Public space. The management dimension, Taylor and Francis Group: France, London-New York, Routledge 2008, pp. 240.

[15] Leclercq E., Pojani D., van Bueren E., Is public space privatization always bad for the public? Mixed evidence from the United Kingdom, Cities 2020, Vol. 100.

[16] Radović D., Boontharm D., Bruzzese A., Cairns S., Fikfak A., Klomp P., Kuma K., Cossio B.M., Medina A., Oguma E., Sim D., Sintusingha S., Verhoeven S., Urban Questions in the Times of Coronavirus. Responding to the Crisis of Public Space, The Journal of Public Space 2020, 5(2), pp. 233-248, DOI 10.32891/jps.v5i3.1362.

[17] Sepe M., Covid-19 pandemic and public spaces: improving quality and flexibility for healthier places, Urban Design International 2021, Volume 26, pp. 159-173, https://doi.org/10.1057/s41289-021-00153-x.

[18] Innocent T., Stevens Q., Urban Play as Catalyst for Social Wellbeing Post-Pandemic, 2021, Front. Comput. Sci. 3:634145. doi: $10.3389 / f c o m p .2021 .634145$.

[19] Aiswarya Raj S., Angella E.J., Pooja C., Impact of Covid-19 in shaping new resilient urban planning approach, Published under licence by IOP Publishing Ltd IOP Conference Series: Materials Science and Engineering 2021, Volume 1114, $6^{\text {th }}$ Biennial International Conference on Emerging Trends in Engineering Science and Technology (ICETEST 2020) $17^{\text {th }}-19^{\text {th }}$ December 2020, Kerala, India.

[20] Honey-Rosés J., Anguelovski I., Chireh V.K., Daher C., Konijnendijk van den Bosch C., Litt J.S., Mawani V., Michael K. McCall, Orellana A., Oscilowicz E., Sánchez U., Senbel M., Tan X., Villagomez E., Zapata O., \& Nieuwenhuijsen M.J., The impact of COVID-19 on public space: an early review of the emerging questions - design, perceptions and inequities, Cities \& Health 2020, pp. 1-20. DOI: 10.1080/23748834.2020.1780074.

[21] Zandieh R., Nieuwenhuijsen M., Zandieh M., Adaptability of Public Spaces and Mental Health Inequalities during the COVID-19 Pandemic, Journal of Urban Design and Mental Health 2020, 6:5. https://www.urbandesignmentalhealth. com/journal-6-covid19-public-spaces.html.

[22] Cackowski J.M., Nasar J.L., The restorative effects of roadside vegetation implications for automobile driver anger and frustration, Environment and Behaviour 2003, 35(6), pp. 736-751.

[23] Mangone G., Exploring urban design strategies that maximize the benefits of urban nature for children's well-being, Ecopsychology 2018, 10(4), DOI: http://dx.doi.org/10.1089/eco.2018.0054.

[24] Jennings V., Bamkole O., The Relationship between Social Cohesion and Urban Green Space: An Avenue for Health Promotion. Int J Environ Res Public Health 2019, 4;16(3), pp. 452. DOI: 10.3390/ijerph16030452. PMID: 30720732; PMCID: PMC6388234.

[25] Kondo M.C., Fluehr J.M., McKeon T., Branas C.C., Urban Green Space and Its Impact on Human Health, Int. J. Environ. Res. Public Health 2018, 15(3), pp. 445. https://doi.org/10.3390/ijerph15030445.

[26] Bil J.S., Buława B., Świerzawski J., Mental Health and the City in the Post-COVID-19 Era, Sustainability 2021, 13(14), 7533. https://doi.org/10.3390/su13147533. 
[27] Tzoulas K., Korpela K., Venn S., Yli-Pelkonen V., Kaźmierczak A., Niemela J., James P., Promoting ecosystem and human health in urban areas using Green Infrastructure: A literature review, Landscape and Urban Planning 2007, Volume 81, Issue 3, pp. 167-178. ISSN 0169 2046, https://doi.org/10.1016/j.landurbplan.2007.02.001.

[28] Shanahan D.F., Astell-Burt T., Barber E.A., Brymer E., Cox D.T.C., Dean J., Depledge M., Fuller R.A., Hartig T., Irvine K.N., Jones A., Kikillus H., Lovell R., Mitchell R., Niemelä J., Nieuwenhuijsen M., Pretty J., Townsend M., van Heezik Y., Warber S., Gaston K.J., Nature - Based Interventions for Improving Health and Wellbeing, The Purpose, the People and the Outcomes, Sports 2019, 7, pp. 141. https://doi.org/10.3390/sports7060141.

[29] Van Gordon W., Shonin E., Richardson M., Mindfulness and Nature, Science+Business Media, LLC, Springer Mindfulness, 2018, pp. 1655-1658.

[30] Pritchard A., Richardson M., Sheffield D., McEwan K., The Relationship Between Nature Connectedness and Eudaimonic Well-Being: A Meta-analysis, Journal of Happiness Studies 2020, Volume 21, pp. 1145-1167. https://doi.org/10.1007/ s10902-019-00118-6.

[31] Hewitt C.N., Ashworth K., MacKenzie A.R., Using green infrastructure to improve urban air quality (GI4AQ), Ambio A Journal of Environment and Societ 2020; 49, pp. 62-73. https://doi.org/10.1007/s13280-019-01164-3.

[32] Hostetler Allen W., Meurk C., Conserving urban biodiversity? Creating green infrastructure is only the first step, Landscape and Urban Planning 2011, Volume 100, Issue 4, pp. 369-371. ISSN 0169-2046, https://doi.org/10.1016/j. landurbplan.2011.01.011.

[33] Cudny W., Appelblad H., Monuments and their functions in urban public space, Norsk Geografisk Tidsskrift - Norwegian Journal of Geography 2019, 73:5, pp.273-289. DOI: 10.1080/00291951.2019.1694976.

[34] Grodach C., Art spaces, public space, and the link to community development, Community Development Journal 2010, Volume 45, Issue 4, pp. 474-493, https://doi.org/10.1093/cdj/bsp018.

[35] Sequeira Á., Ephemeral Art in Impermanent Spaces: The Effects of Street Art in the Social Construction of Public Space, In Urban Interventions: Street Art and Public Space, Costa, P.; Neves, P.,S.; Guerra, P.; Eds.; Lisboa: 2016, pp. 65-74. urbancreativity.org.

[36] Jażdżewska I., Murals as a Tourist Attraction in a Post-Industrial City: A Case Study of Łódź (Poland), Tourism 2018, 27(2); pp. 45-56.

[37] Honghao He, Wu M., Gyergyak J., Intervention and renewal - Interpretation of installation art in urban public space, Pollack Periodica, An International Journal for Engineering and Information Sciences, AKJ Journals, DOI: 10.1556/606.2021.00362.

[38] Szostak A.J., Methodology of visual art localization in public spaces, on example of Poznan City, Town Planning and Architecture 2007, XXXI(1), pp. 29-38.

[39] Szostak A.J., The role of public visual art in urban space recognition, In Cognitive Maps, Perusich, K., Edt.; Croatia: INTECH, 2010, pp. 75-100.

[40] Dziadzia B., Głyda-Żydek B., Piskorek-Oczko S., Eds., Artystyczne wymiary wytwarzania kapitału społecznego i kulturowego, red. Fundacja Animacji Społeczno-Kulturalnej Bielsko-Biała, Cieszyn 2015.

[41] Rzymełka-Frąckiewicz A., Wilk T., Sztuka w przestrzeni społecznej - wymiar artystyczny i edukacyjny „Chowanna”, 2019. pp. 369-382.

[42] Zebracki M., Public art as conversation piece: scaling art, public space and audience, Belgeo, 2014, 3, Online since 19 December 2014, connection on 20 April 2019, http://journals.openedition.org/belgeo/13381; DOI: 10.4000/belgeo.13381.

[43] Przesmycka N., Boguszewska K., Landscaping of green areas in the urban layout of midtown Lublin, TEKA, 2020, Vol. 4, Komisji Architektury, Urbanistyki i Studiów Krajobrazowych, Oddział Polskiej Akademii Nauk w Lublinie, pp. 70-85.

[44] Pietrzyk B., Wielokulturowy Lublin: komunikacja przestrzeni fizycznej i społecznej. Pogranicze, Polish Borderlands Studies 2016, t. 4, nr 2, pp. 281-297.

[45] Trzaskowska R., Adamiec P., Diagnoza stanu i walorów parków miejskich Lublina oraz wytyczne do ich ksztattowania, Teka Kom. Arch. Urb. Stud. Krajobr. - OL PAN, 2012, VIII/1, pp. 7-18. https://journals.pan.pl/Content/94317/mainfile.pdf.

[46] Whyte W.H., The social life of small urban spaces, Project for Public Spaces, New York, 2001.

[47] Project for Public Spaces. What makes a successful place? 2018, Available from: http://www.pps.org/topics/gps/gr_place_feat. (accessed on 2005 2021). 